\title{
COMMUNITY RESILIENCE: LESSONS FROM RECENT DISASTERS
}

\author{
Lesley C. Ewing, PE, D.CE, M.ASCE ${ }^{1}$ and Costas E. Synolakis, Ph.D., M.ASCE ${ }^{2}$
}

\begin{abstract}
Resilience occurs at many levels, from global and national to family and individual. Community and local government efforts for resilience fit in the middle of this spectrum. Major community elements that are important both for minimizing vulnerability and hasten recovery include transportation, communication, water, energy, emergency services and housing. Coastal areas have some special concerns for vulnerabilities that can arise from coastal hazards such as tsunamis, hurricanes, storms, flooding, and erosion; lessons from recent coastal disasters provide recommendations for improved disaster management and community resilience. Resilience is not a one-time effort that can arise from a single approach; it is an ongoing community process, resulting from a combination of approaches. A Community Resilience Index (CRI) can help communities recognize their resilience strengths and opportunities for improvement. A "bare-bones” Community Resilience Index (CRI) has been developed based upon lessons learned from recent coastal disasters. The utility of the CRI is tested for recent community disasters at Galveston, Texas from Hurricane Ike, at American Samoa from the 2009 Samoan tsunami and at Pacifica, California from the 2009/2010 winter storms. Case studies will help identify additional CRI factors that will expand the focus of the CRI and improve overall community disaster management and coastal resilience.
\end{abstract}

Keywords: disaster management; hazards; vulnerability; Community Resilience Index

\section{INTRODUCTION}

Importance of Coastal Communities

Coastal areas have been the centers of human development for hundreds, if not thousands of years. Coasts, especially river deltas, provide opportunities for housing, commerce, fishing, aquaculture, agriculture, and forestry, the ability to transport goods to areas both along the coast and to inland areas, and access to freshwater. Almost 40\% of the world's population lives within $100 \mathrm{~km}$ of the coast; and while coastal lands at or below the 10 -meter elevation make up only $2.2 \%$ of the global land area, approximately 600 million people (10\% of the global population) live in these low-lying areas (McGranahan et al. 2006).

During the past century there has been a general migration of people from rural to urban areas with increases occurring to coastal cities and inland cities alike. As of 2008, there were 20 megacities, urban areas with over 10 million people. Fourteen of these megacities are located along the coast and several more coastal cities are likely to become megacities in the coming decade (Ewing 2008).

Globally approximately $\$ 944$ trillion (US) of the global Gross Domestic Product (GDP) is situated between Mean High Water (MHW) and 1-m MHW, and \$1,802 trillion (US) is situated lower than 5-m MHW(Anthoff et al. 2006). In the United States, approximately 75\% of the 2000 State GDP came from coastal states. Approximately 50\% of the State GDP came from coastal watershed counties, and 11\% came from lands immediately adjacent to the coast (Colgan 2003). By 2004, GDP for all shoreline adjacent counties was $\$ 4.68$ trillion (US), and the national ocean economy GDP was $\$ 138.3$ billion (US) (National Ocean Economy Program; www.oceaneconomics.org). The coastal and ocean economies are important and significant parts of the national economies of all non-landlocked nations.

\section{Coastal Hazards, Vulnerability, Disasters and Resilience}

Much of the strength of coastal economies depend upon ready access to open water and the resultant commercial and trade opportunities; however, this same access to open water can also expose development and resources to coastal hazards such as storms, flooding, hurricanes, tsunamis and erosion. There is a balance between building along the coast to take advantage of water access and coastal resources, and building in locations that are inherently hazardous. A hazard "is a threat to people and things they value” (Cutter 2001). Hazardous events can cause injuries and fatalities; damage or destroy housing, businesses, industrial development, roads, ports and community services; and, disrupt or destroy commerce and trade. Yet, hazardous coastal events are part of the continuum of normal coastal processes. Gentle waves build up beaches, bring energy to the coast and provide nutrient exchange from beaches to the inter-tidal areas; storm waves that can erode beaches, scour

\footnotetext{
${ }^{1}$ California Coastal Commission, 45 Fremont Street, Suite 2000, San Francisco, CA 94105, USA.

2 Department of Civil and Environmental Engineering, University of Southern California, Los Angeles, CA, 900890373, USA.
} 
foundations, bridges and roads, and destroy buildings have their origins in the same processes as these gentle waves.

Coastal hazards arise from peoples' need or desire to be close to the coast; hazards also have "a potentiality to them (they could happen)" (Cutter 2001). For most coastal hazards, the issues are not if they can happen, but, when they will happen and the size or magnitude of the event. What may be hazardous to one asset may not be hazardous to another asset; for example, a small storm may flood a building at grade, but may have no impact upon a pile-supported building. At some point, a hazardous event will be at a scale such that is becomes a disaster - "a singular event that results in widespread losses to people, infrastructure, or the environment” (Cutter 2001).

Recent events such as the 2004 Indian Ocean, 2009 Samoan and 2010 Chilean tsunamis, the various hurricanes, typhoons, coastal floods, winter storms and El Niños can all be considered coastal disasters. They have brought attention to many of the dangers inherent with developing close to the coast and have also increased interest in finding ways to build or rebuild in coastal areas in ways that will minimize damages in future. One method for rebuilding after a disaster has been to use the characteristics of the event as the metric for the design. And, if the disaster event is close to the extreme that can occur, then designing for this event can help minimize future damages. However, if the damaging event is not the worst event that can occur, if the event has no extreme, or if the extreme will change in the future, as may occur with rising sea level and climate change, the process of designing for the last event may do little to reduce the damages that can occur in the future.

A concept that has become increasingly important in disaster management is resilience, where resilience encompasses both the ability to continue to function during and after some disruptive or disastrous event, and the ability to recover after the event. Figure 1 shows these two aspects of resilience.

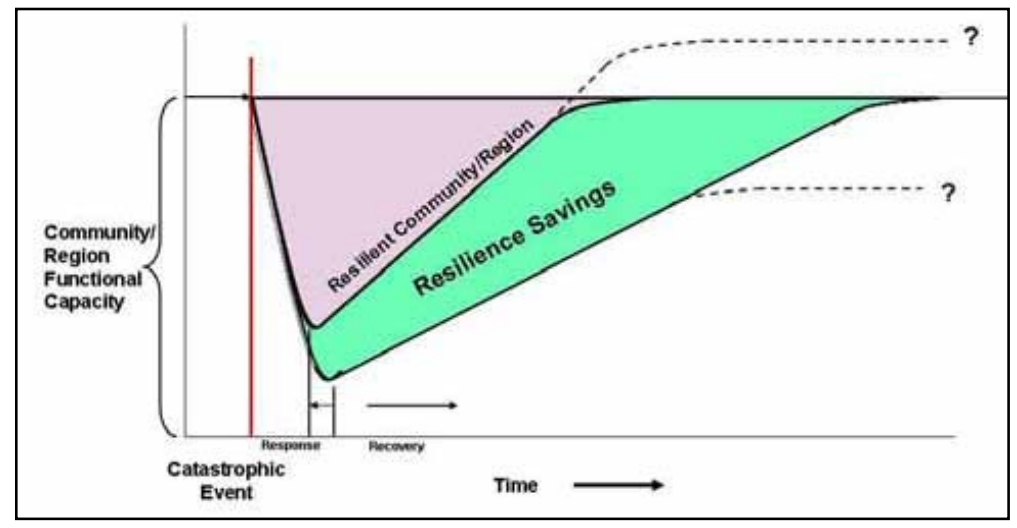

Figure 1. Community resilience and functional capacity (National Oceanic and Atmospheric Administration 2010).

\section{COMMUNITY RESILIENCE INDEX}

\section{Elements for Community Resilience}

Resilience occurs on many difference scales - from individual resilience to national and international resilience. Community resilience fits in the middle of this spectrum of resilience, providing the bridge between individual and family resilience and state/national resilience.

Communities provide a broad array of services, from water and waste disposal to civil defense, education, street cleaning, open space, land use planning, and environmental quality. Along the coast, communities may also be responsible for flood protection, beach access and nearshore water quality. There are numerous studies that identify critical systems that can establish community elements. The American Society of Civil Engineers provides an Infrastructure Report that evaluates aviation, bridges, dams, drinking water, energy, hazardous waster, inland waterways, levees, public parks and recreation, rail, roads, schools, solid waste, transit and wastewater (ASCE 2009). The Department of Homeland Security identified critical infrastructure and key resource sectors as agriculture and food, defense industry base, energy, healthcare and public health, national monuments and icons, banking and finance, water (drinking water and wastewater systems), chemical, commercial facilities, critical 
manufacturing, dams, emergency facilities, nuclear reactors, material and waste, information technology, communications, postal and shipping, transportation systems, and government facilities. Working from these lists of infrastructure and resource sectors, six key community elements have been identified as use for indicators of resilience to coastal disasters at the community level. These include:

- Transportation

- Power

- Water

- Communications

- Emergency Services

- Housing

These factors form the core of essential community services with which other community needs can be quickly established. They may not be appropriate for disasters at other scales since they assume some efforts will have been in place at the individual scale for resilience. It also assumes that, at a larger regional, state or national scale, or global scale in the case of small island nations, that supplies and services will be available to provide post-disaster relief. For example, food and agriculture are clearly important at all scales of resilience; however, most urban areas already get much of their food from outside the urban boundary and with a viable transportation link, food can readily be brought into the affected areas. Power can run refrigeration units to keep perishable foods safe or pumps to remove water from low-lying areas. Communication systems can notify people where to go for food and water, and provide information on missing persons or direct rescue efforts. Emergency services can provide immediate health care and, if transportation systems are available, can get people to hospitals and medical centers.

The first five core community elements -- transportation, power, water, communications and emergency services -- are all services that are normally expected to be provided at a community scale. Certainly some individual building have solar panels for power and private driveways or entrance roads for transportation, some store water, and maintain short wave or ship-to-shore radios, walkietalkies, and first aid kits; however, these are services (transportation, communications, power, water and emergency services) that fall generally into the idea of community infrastructure, municipal utilities or services. And these services are inter-related. The water treatment plant needs power, the power system needs a transportation system for access to transmission and distribution lines and substations, hospitals and emergency services need power for lights and to run the air conditioning and medical equipment, need clean water for sanitation and transportation to get people in and out of the facilities. Housing, outside of "company towns" and campus systems, is mostly considered to be an individual responsibility. However, all the services that are essential for community function during and after a disaster need people to keep the systems working, and people generally will not address long-term recovery until they have shelter. For example, Hurricane Katrina did not seriously damage the gulf coast ports and the ports were able to get their facilities back into working order soon after the disaster. However, most of the skilled port workers had lost their housing in the hurricane and they were not able or willing to return to work until they had first secured safe living space for themselves and their family (Curtis 2007). And, five years after Hurricane Katrina, the shortage of habitable buildings in downtown New Orleans seem to be one of the impediments to recovery. And, even though housing is not a community service, it can be a community responsibility through land use planning, building codes and issuance of building permits, and it has been included in the core elements.

\section{Resilience}

Resilience is not a unique trait, but is rather a combination of traits or characteristics that can reduce community vulnerability. Neither is it a single step, but is rather an on-going effort. At the broadest scale, coastal resilience can extend to governance, society and economy, coastal resource management, land use and structural design, risk knowledge, warning and evacuation, emergency response, and disaster recovery (Jonientz-Trisler et al. 2005; U.S. Indian Ocean Tsunami Warning System Program 2007). Within the areas of engineering and coastal processes, resilience includes elements such as resistance to hazards, options for functional redundancy or substitutions, and steps for reductions in exposure and vulnerability. Jonientz-Trisler at al. (2005) identified five aspects of resilience for tsunamis, that, expressed for hazards (and not just tsunamis) are:

(1) understand the nature of the hazard

(2) have the tools needed to mitigate the risk 
(3) disseminate information about the hazard

(4) exchange information with other at-risk areas

(5) institutionalize planning for a disaster.

Knowledge and awareness of the hazard are fundamental to the concept of resilience. Knowledge of vulnerabilities and risks are also important. Coastal processes and the related physical phenomenon such as waves, run-up, currents, storm surge, sediment movement, scour, erosion, deposition and shoaling need to be understood to identify hazard vulnerability and options to either reduce vulnerability or increase resilience.

The physical aspects of coastal hazards have been studied for many years and there is sufficient understanding of many of the hazards that the causal events can be identified. For example, the generating mechanisms for tsunamis are understood and most historic “orphan" or "source-less" tsunamis have been linked to far-field earthquakes, submarine slides or meteor strikes. Hurricanes and typhoons can be tracked as they grow from tropical storms to more significant events and the surge can be estimated based upon local tides and topography and the anticipated storm track and arriving wind speed. Spreading and landfall of surface oil from the recent Deepwater Horizon well could be anticipated from information about the winds, currents and circulation patterns in the Gulf of Mexico. Models can also extend hazard information from what is available in the historic record to information about what could happen. Communities need not experience a major earthquake, tsunami or storm or hurricane to know potential areas of high ground shaking, soil liquefaction, inundation, erosion, slope failure, or damage. Historic trends and knowledge of potential hazards can provide communities with a vast awareness of possible future hazards to which they may be vulnerable. Since resilience is the reverse of vulnerability, knowledge of vulnerability can provide a strong foundation for resilience planning.

Understanding of coastal hazards has changed significantly over time. In the past, hazardous events and disasters were viewed as randomly destructive occurrences or "acts of god". As disasters recurred, there was an awareness of patterns or causal explanations for the events. And people became aware that there were some "normal" conditions and some extraordinary or abnormal events. Along with the awareness of coastal conditions, came a basis for considering the concepts of risk and vulnerability. Knowledge of past disasters has been important in this examination of coastal hazards. However, with the changes in climate and sea level that are projected to occur from the continued emission of carbon dioxide and other greenhouse gases, many hazards will no longer follow historic patterns. Study of hurricanes patterns have found that changes in both hurricane frequency and intensity can be connected to changes in sea surface temperatures and greenhouse gas forcing (Mann and Emanuel 2006; Mann et al. 2007). Changes in sea level will change nearshore waves and wave run-up, tsunami inundation, erosion and sedimentation patterns, bluff erosion and shoreline trends (Ewing 2009; Komar et al. 2008; Ruggiero 2008). Even the manner for projecting changes in sea level will change and historic trends for rising sea level are not expected to be good indicators for future sea level. Figure 2 shows the range of some of the more recent projections, developed from semi-empirical projections of sea level based global climate model projections of future temperature for various emission scenarios and upon historic relationships between changes in temperature and sea level.

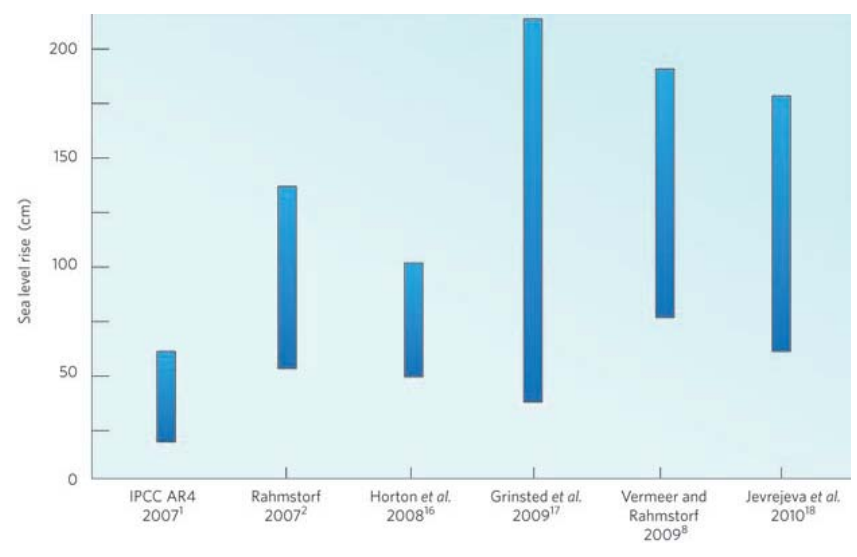

Figure 2. Ranges of sea level rise. Projections for twenty-first century sea level rise from semi-empirical models, as compared to the IPCC Fourth Assessment Report. (Source: Rahmstorf 2010, from (Grinsted et al. 2009; Horton et al. 2008; IPCC 2007; Jefrejeva et al. 2010; Rahmstorf 2007; Vermeer and Rahmstorf 2009) 
The recent interest in resilience has likely been due to the combination of both a concern about the vulnerability of coastal communities with rising sea level and climate change and the damages to coastal areas around the world from significant coastal disasters - the 2004 Indian Ocean tsunami, the 2005 hurricane season in the Gulf of Mexico (with five major hurricanes in one season, Dennis, Emily, Katrina, Rita and Wilma), 2008 Hurricane Ike and Cyclone Nargis, the 2009 Samoan tsunami, the 2009/2010 El Niño storms, fatal floods in the south of France, the Haitian earthquake, earthquake and tsunami in Chile and oil spill in the Gulf of Mexico. These extreme events have highlighted some of the weaknesses in the current coastal protection efforts that have, to date, relied heavily upon resistance and hard armoring. These events have also provided opportunities to learn from past disasters so that communities can be more resilient in the future.

A goal of a resilience community would be to minimize the occurrence of disasters. Hazardous events will happen and some damage will be inevitable from large events; but large events do not need to result in a disaster. The hazardous events such as storms, hurricanes and tsunamis are not avoidable, but the consequences of the events, the loss of human life, property and essential services, can be avoided when a community is resilient. Even hazardous events with human sources, like the Gulf oil spill, are not completely avoidable. Certainly oversight efforts and checks on the engineering might minimize future events, but no control system is infallible. Resilience includes an awareness of vulnerabilities and planning for ways to protect important services if protective measures do not work as anticipated.

The trend of a hazard can influence resilience. Clearly, if a hazard can be expected to remain constant or to lessen over time, attention to a hazard can remain constant without a decrease in resilience. However, most hazards can be expected to increase in the future, as would be the case with extend of inland flooding or shoreline erosion with rising sea level. For concerns that will increase with time, resilience will decrease unless the community pays increasing attention to those risks. The trend of the community will also influence resilience. If a non-resilience community returns to the same condition after a disaster, it will remain at risk to future disasters and over time will become less resilient if the hazard intensity increases. Communities that are working on resilience and reduced vulnerability prior to a disaster have a momentum to turn the disaster to an advantage; options for sustained resilience had likely been examined and there will be opportunities for improving the resilience of the new, post-disaster community by implementing some of these new ideas.

\section{Lessons Learned from Past Disasters}

One lesson repeated from almost all coastal disasters is the value of elevation. For disasters where water is the main source of damage and destruction, elevation above the maximum water level can keep people and the things they value away from most of the danger. Hurricane Katrina showed only too well the dangers of placing buildings and utilities at or below sea level. One key lesson learned from hurricane damage assessments is that if buildings are built so that the lowest floor members are above the elevation of the waves and flood waters, most buildings can survive the event (Ewing et al. 2009). The only area where elevation may be detrimental is with roadways ${ }^{3}$. Elevated roads seem to experience significantly more damage than at-grade roads, possible the result of flood waters receding as sheet flow, where the elevation difference sets up a hydraulic jump, that scours the roadway support.

Two other important lessons from recent disasters are the benefits of effective shore protection and effective scour protection. The Indian Ocean tsunami provided many examples of shore protection benefits to inland properties, as did Hurricane Ike. Shore protection can take many different forms. In Thailand, a traditional low seawall protected inland buildings from the main force of the waves by deflecting much of the wave momentum skyward (Dalrymple and Kriebel 2005). Field investigators on Karon Beach, Phuket concluded that low elevation dunes dissipated wave forces so the inland development experienced only a gradual rise in water level, without the damaging wave forces that destroyed nearby development with the dunes have been lowered to provide better views of the ocean (Synolakis and Bernard 2006). Other investigators attributed some of the inland penetration of waves in Sri Lanka to the mining of offshore coral, thus minimizing the normal wave dissipation that is provided by reefs (Liu et al. 2005) - an example of the consequences of ineffective shore protection.

${ }^{3}$ Environmental forcing from wind and seismic loads can increase with building elevation. Building design must, of course, take these multiple-loading factors into account. 
The Galveston Seawall protected much of downtown Galveston from erosion and gulf-side flooding during Hurricane Ike; however, ;ow-crested sand-filled geotube berms that has been installed for storm and erosion protection along parts of the Texas coast were not sufficiently high to provide effective protection and many of the buildings inland of these berms were destroyed by waves and flooding (Ewing et al. 2009). In Samoa and American Samoa, many buildings inland of engineered shore protection were protected from erosion and scour; however, when waves destroyed an underdesigned revetment on Upolu, the revetment stones became projectiles and damages some of the inland buildings (personal observations by the authors).

Scour is another major source of coastal damage. As noted earlier, elevated roads can be damaged from scour during sheet flow of floodwaters. Piles can elevate buildings above the flood waters, but this elevation is only useful if the piles are embedded deeply enough to protect from scour. There were examples from Hurricane Ike of scour damage when piles had only 5 or 6 feet of embedment depth. Based on broad observations of scour damage, FEMA prepared an advisory on erosion and scour that recommends embedment depths of 10 to 20 feet, depending on pile diameter and expected wave conditions (FEMA 2009).

Some of the development aspects that can affect building survival are the adherence to building codes, building orientation and the use of a pass-though lower story. Building codes have been important for building survival; however, these standards tend to follow the previous disaster. The first steps for fire-safe buildings resulted from major fire losses; likewise the first seismic standards for buildings followed major building losses from an earthquake. Nevertheless, building codes provide for the minimally acceptable standards for building construction to insure survival from most of the likely forces to which the structure will be subjected. The goal for extreme events is life-safety. A building may be uninhabitable following an extreme event, but can be considered to have been successful if it does not collapse or cause loss of life during the event. Some of the observations from the Indian Ocean tsunami were that buildings with their long dimension oriented to the direction of the waves fared better than those whose long dimension was perpendicular to the wave forces (Synolakis and Bernard 2006). A second observation was that pass-through lower stories, a feature used for many years for flood protection, could also be useful during tsunamis (Dalrymple and Kriebel 2005).

The final four lessons learned from past disasters focus mainly upon actions at the community level. They include the use of an early warning system for hazard events, undertaking a vulnerability and risk assessment to gain proper understanding of both the areas and facilities within the community that are vulnerable to various hazards and the risks or consequences of damages or losses from an event, determining opportunities for adaptation and the development of functional redundancy.

Tracking systems have been for many years for hurricanes and tropical cyclones and these efforts provide the basic for early warnings of the events and the likely landfall locations. The hurricanes do not always follow the predicted paths or make landfall at the expected locations, but the main components are in place for the international weather services to provide broad-based warnings for most cyclonic storm events. More recently, tsunami detection systems have been installed in most of the tsunami-prone regions of the world to provide an early warning of far-field events. In addition to these formal warning systems, educational efforts have attempted to alert people to the natural warning signs of a tsunami (ground shaking, a rapid drawdown of water or strange noises from the ocean) when the generating source may be too close for the automatic tsunami detection system to be effective. Of course, information about what to do if there is a storm, hurricane, tropical cyclone, or tsunami, must be part of all the warning systems, since knowing an event is imminent without knowing how to prepare for the event, makes the main life-saving purpose of the warning system ineffective.

Information on local vulnerabilities and risks are a complement the warning system. Knowledge that certain areas or types of structures are very likely to be at risk from the event will be important for people as they determine what to do with the early warning. For example, evacuation to high ground is a routine response to a tsunami warning; but effective evacuation needs to have routes that do not go through low-lying areas to get to higher ground. Vertical evacuation in a strong high-rise building may be effective; but people need to have some assurance that the building will be safe and they need to know how high to go. And evacuation of people from safe locations can impede the evacuation efforts of people who are not already in safe locations.

Information on vulnerabilities and risks can also help evaluate the consequences of unanticipated events. One element of vulnerability that is difficult to quantify and convey to the local community involves that efficacy of existing structures. As noted earlier, ineffective protection may not only put inland development at risk, it can actually endanger inland development. Shoreline structures and flood 
defenses are designed for some level of safety. For older structures, the level of safety may not be explicitly identified, and for all structures, the actual level of safety may differ from the anticipated level of safety. When structures are not well-maintained, as is the case for lots of urban infrastructure ${ }^{4}$, the level of safety will drop over time, and smaller and smaller events will be able to cause structural damage or destruction (Institution for Civil Engineers 2008). While these changes may be difficult to quantify, communities need to understand the actual effectiveness and protection that can be expected from existing structures.

Finally, information on vulnerabilities and risk can be used to determine opportunities for adaptation to reduce the consequences of hazards (such as building elevation or relocation, or converting the ground floor of a building into a pass-through floor). The information can also help determine where functional redundancy may be useful. For example, a coastal road may be important for tourist travel and access to coastal development; however, if this road is not likely to be able to provide rapid ingress and egress during or after a storm event due to flood waters, over-wash, or scour, it may be important to have a redundant inland route that will be available during and after the event.

Adaptation and redundancy are now part of disaster preparedness plans and they will become even more important in the future for resilience planning. One of the techniques used to facilitate rapid evacuation of hurricane areas is reverse-flow, to switch all roadways to lead out of the potential inundation areas. This technique adapts existing roadways to provide redundant transportation systems. With rising sea level, adaptation will become more important to maintain current community assets and hazard protection. And, if managed retreat becomes a viable option for addressing chronic shoreline erosion and repeated hazards, a redundant inland system for critical core community elements can be used to replace shoreward systems as they become too vulnerable to maintain effectively.

\section{Factors for a Community Resilience Index}

A community resilience index (CRI) is a tool for communities to evaluate resilience, to evaluate how resilience may change with various changes to programs or structures, or determine whether the community is becoming more or less resilient over time. Factors going into a CRI need:

- Help minimize initial drop in function

- Help improve recovery time

- Help improve future community function

And, communities must be able to have some control over the CRI factors.

Many factors will influence whether a hazardous event will become a disaster. For example, if the peak of a storm arrives during low tide, there will likely be a much smaller amount of damage than if it were to arrive during an extreme high tide. But since the community has no influence over the arrival time of a hazard event, this is not a factor that would be included in the CRI. An initial CRI was developed from four resilience factors that either individually or collectively can help maintain community functions or minimize the drop in function, can improve future community function and that can be modified by community action. These four include:

- Local Susceptibility to hazards

- Exposure

- Availability of safe Substitute/Redundant Services

- $\quad$ Recovery Time

Initially all four factors have been given equal ranking; however, with further examination, some type of factor weighting may be more appropriate. And, additional factors may be added if gaps or weaknesses are identified with a CRI that relies only upon these four factors.

Local susceptibility to hazards uses the Coastal Vulnerability Index that was developed by the US Geological Survey (Thieler and Hammar-Klose 2000), initially to determine vulnerability of the US coast to sea level rise. The initial CVI development included preparation of broad-based geographic data sets (for geomorphology, coastal slope, relative sea level change, shoreline erosion/accretion,

\footnotetext{
${ }^{4}$ The most recent Infrastructure Report card by the American Society of Civil Engineers found none of the infrastructure at the national level to be better than mediocre; most of the infrastructure was found to be in poor condition and drinking water systems, inland waterways, levees and wastewater systems were only one step above failing ASCE. (2009). "2009 Report Card for America's Infrastructure." ASCE, Reston.
} 
mean tide range, and mean water height) for use in determining regional-scale vulnerabilities. These values may not be appropriate for small areas, but the overall concept is applicable and more appropriate local values for each variable in the CVI can be developed. One concern with the CVI is that the input factors seem to be beyond the control of the community; however, some of the factors can be modified by human intervention. Figure 3 highlights the factors that a community might be able to modify - for example, installing or removing a breakwater can change mean wave height, undertaking beach nourishment or sand back-passing can modify beach slope, and beach nourishment and armoring can modify erosion or accretion patterns. So, while the CVI, in general, covers regional factors that are out of the control of individual communities, the general framework can be examined on the local level to identify local susceptibility to coastal hazards.

\begin{tabular}{|c|c|c|c|c|c|}
\hline & \multicolumn{5}{|c|}{ Ranking of coastal vulnerability index } \\
\hline & Very low & Low & Moderate & High & Very high \\
\hline VARIABLE & 1 & 2 & 3 & 4 & 5 \\
\hline Geomorphology & $\begin{array}{l}\text { Rocky, cliffed coasts } \\
\text { Fiords } \\
\text { Fiards }\end{array}$ & $\begin{array}{l}\text { Medium cliffs } \\
\text { Indented coasts }\end{array}$ & $\begin{array}{l}\text { Low cliffs } \\
\text { Glacial drift } \\
\text { Alluvial plains }\end{array}$ & $\begin{array}{l}\text { Cobble beaches } \\
\text { Estuary } \\
\text { Lagoon }\end{array}$ & $\begin{array}{l}\text { Barrier beaches } \\
\text { Sand Beaches } \\
\text { Salt marsh } \\
\text { Mud flats } \\
\text { Deltas } \\
\text { Mangrove } \\
\text { Coral reefs }\end{array}$ \\
\hline Coastal Slope (\%) & $>0.115$ & $0.115-0.055$ & $0.055-0.035$ & $0.035-0.022$ & $<0.022$ \\
\hline $\begin{array}{l}\text { Relative sea-level } \\
\text { change }(\mathrm{mm} / \mathrm{yr})\end{array}$ & $<1.8$ & $1.8-2.5$ & $2.5-3.0$ & $3.0-3.4$ & $>3.4$ \\
\hline $\begin{array}{l}\text { Shoreline erosion } \\
\text { accretion }(\mathrm{m} / \mathrm{yr})\end{array}$ & \multicolumn{2}{|c|}{$>2.0 \underset{\text { Accretion }}{1.0-2.0}$} & $\begin{array}{c}-1.0-+1.0 \\
\text { Stable }\end{array}$ & \multicolumn{2}{|c|}{ Erosion } \\
\hline Mean tide range (m) & $>6.0$ & $4.1-6.0$ & $2.0-4.0$ & $1.0-1.9$ & $<1.0$ \\
\hline $\begin{array}{l}\text { Mean wave } \\
\text { height }(\mathrm{m})\end{array}$ & $<0.55$ & $0.55-0.85$ & $0.85-1.05$ & $1.05-1.25$ & $>1.25$ \\
\hline
\end{tabular}

FIGURE 3: Coastal Vulnerability Index, for local susceptibility (Source: Modified from Thieler et al. 2000)

Exposure provides a way to determine how many important community functions are vulnerable to coastal hazards. Communities should have some information on the areas that have the potential for inundation, the areas that are exposed to erosion or subsidence, areas which, over time, could be hit by storm waves or tsunami runup. If vulnerability maps have not been prepared, then historic disasters or events of regional significance may provide a good first approximation of the locations vulnerable to coastal hazards, allowing some determination of the facilities and community functions that can be exposed to hazardous events.

The availability of safe substitute or redundant community functions goes together with exposure. Ideally, if there are a number of community functions that are exposed to coastal hazards, then there will be options to maintain functionality if the coastal facilities are damaged or destroyed. If, for example, the road right next to the coast is the only direct route through the community, the transportation is exposed to coastal hazards and has no substitution. Alternatively, if there is an inland road in addition to the coastal road, then there may be options for community transportation following a major event. Redundancy was identified as a resilience factor in addition to exposure since it addresses the function more than the actual facilities. So, in the case of communications, telephone lines may be located in a vulnerable area, yet there are options for cell towers or short-wave radios that provide redundancy, despite the exposure of one of the main communication facilities.

Recovery time is a final concern for resilience. Some facilities are designed to be brought back on line rapidly and other facilities may have many impediments to prevent rapid redeployment. If roads are out of service because they are covered with debris, they can become passable once the debris is removed. If a bridge is out of service because the access ramp has been washed away or an abutment has collapsed due to scour, then recovery can be much longer. While recovery times will vary with each event, they can be estimated from an understanding of the main facilities and functions that can be exposed to hazards and consideration of various damage scenarios. 
Figure 4 shows the full CRI with each of the factors that would make up the main index. Each resilience factor will be assessed separately and combined additively for a numerical index and the values are normalized for a 1 to 100 scale.

\begin{tabular}{|l|c|c|c|c|c|}
\hline $\begin{array}{l}\text { Coastal } \\
\text { Resiliency } \\
\text { Index }\end{array}$ & $\begin{array}{c}\mathbf{1} \\
\text { Very Low }\end{array}$ & $\begin{array}{c}\mathbf{2} \\
\text { Low }\end{array}$ & $\begin{array}{c}\mathbf{3} \\
\text { Moderate }\end{array}$ & $\begin{array}{c}\mathbf{4} \\
\text { High }\end{array}$ & $\begin{array}{c}\mathbf{5} \\
\text { Very High }\end{array}$ \\
\hline $\begin{array}{l}\text { Hazard } \\
\text { Susceptibility } \\
\text { (CVI) }\end{array}$ & $\begin{array}{r}5 \\
\text { Very High }\end{array}$ & $\begin{array}{c}4 \\
\text { High }\end{array}$ & $\begin{array}{c}3 \\
\text { Moderate }\end{array}$ & $\begin{array}{c}2 \\
\text { Low }\end{array}$ & $\begin{array}{c}1 \\
\text { Very Low }\end{array}$ \\
\hline $\begin{array}{l}\text { Community } \\
\text { Elements } \\
\text { Exposed }\end{array}$ & $>90 \%$ & $60-90 \%$ & $30-60 \%$ & $10-30 \%$ & $<10 \%$ \\
\hline $\begin{array}{l}\text { Safe } \\
\begin{array}{l}\text { Functional } \\
\text { Redundancy }\end{array}\end{array}$ & $\begin{array}{c}\text { Backups for } \\
0 \text { of } 6\end{array}$ & $\begin{array}{c}\text { Backups for } \\
1 \text { or } 2 \text { of } 6\end{array}$ & $\begin{array}{c}\text { Backups for } \\
3 \text { of } 6\end{array}$ & $\begin{array}{c}\text { Backups for } \\
4 \text { or } 5 \text { of } 6\end{array}$ & $\begin{array}{c}\text { Backups for } \\
6 \text { of } 6\end{array}$ \\
\hline $\begin{array}{l}\text { Recovery } \\
\text { Time }\end{array}$ & $>2$ months & 1 to 2 months & 2 to 4 weeks & 1 to 2 weeks & $<1$ week \\
\hline
\end{tabular}

FIGURE 4: Coastal Resiliency Index

\section{COMMUNITY RESILIENCE CASE STUDIES}

There have been a number of communities that can be used to test the relevance of the proposed coastal resiliency index. Initial test cases draw from communities that have recently experienced a significant coastal hazard event. From the recent events, three different type and scale events were identified for examination. These communities include Galveston, Texas, that was affected by Hurricane Ike (2008), Tutuila, American Samoa that was affected by the Samoan tsunami (2009), and Pacifica, California that was affected by El Niño storms and erosion (2009/2010).

\section{Galveston, Texas: Hurricane Ike}

Galveston, Texas is an urban community located on a barrier island, south of Houston, Texas, on the Gulf of Mexico. The population is over 288,000 (2008 census) residents and during summer vacation and on spring break, the population can swell to over half a million along 52 kilometers of coast. In 1900 the island was overwashed by a major storm (likely a hurricane), more than 6,000 people were killed and most development on the island was destroyed. In response to this storm, a large seawall was build along the Gulf coast and the developed part of the island was elevated. From 1900 to 2008, nine hurricanes of Catergory 3 or above and over 30 hurricanes of Category 1 or 2 passed within 100 kilometers of Galveston (Ewing et al. 2009) and several of these inundated parts of the island.

The portions of the island west of the seawall have erosion rates up to 1.65 meters/yr (Morton and McKenna 1999). This high rate of erosion moves the shoreline inland rapidly - often during large storm events. The area that is vulnerable to erosion and storms is dynamic and survival from one storm is no assurance that the same property will be safe during future events, although the Galveston Seawall halted inland shore migration and provided significant protection to inland properties on the eastern portion of the island.

Hurricane Ike traveled up Galveston Bay on September 13, 2008. Bolivar Island, on the eastern side of the storm took the brunt of the storm and much of the development on the island was destroyed. The seawall protected the Gulf side of the city from erosion and major inundation, but portions of downtown Galveston flooded when water in the bay was pushed into the city. Communities that were not protected by the seawall experienced significant erosion and flooding; this was true even for the areas fronted by geotube sand berms. Most of the community facilities are close to the coast or are in low-lying areas; redundant services are located off the island. Most ground transportation and communications were back in service within about a week; power lines had been replaced within the month and water lines took several months. Temporary housing was available within a few weeks, but permanent housing had not been fulling restored even a year after then event. 


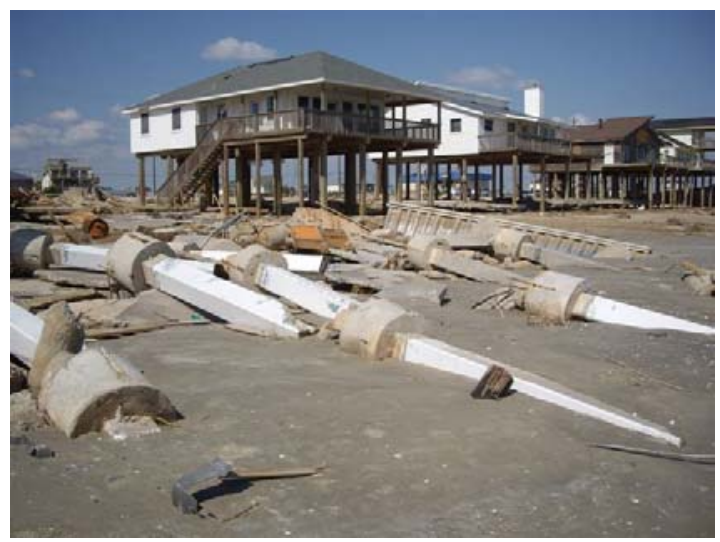

FIGURE 5: Sea Isle Beach, Galveston, TX. Evidence of Scour Damage from Hurricane Ike

\section{Tutuila, American Samoa: Samoan Tsunami}

Tutuila, the main island of American Samoa, is an ancient volcanic island, close to a Pacific plate subduction zone. The $142-\mathrm{km}^{2}$ island is subject to frequent hurricanes, tropical storms and, less frequently, to tsunamis. The island's population is approximately 56,000 (from the 2000 census). There are approximately 115 kilometers of shoreline and most of the large population centers are located along the coast, with the capitol, Pago Pago,is located on the southern coast, around a natural deepwater harbor.

A strong earthquake occurred on the morning of September 29, 2009, the epicenter was between the islands of Samoa and Tonga; a tsunami was generated and the first waves arrived at Samoa within 15 to 20 minutes of the seismic event; there were 34 fatalities on Tutuila from the tsunami and 189 fatalities on the Samoan and Tongan Islands in total. Maximum run-up amplitudes varied significantly around the island of Tutuila. Some of the largest run-up amplitudes were observed at the east and west ends of the island, along the central portion of the north shore, and in Pago Pago Harbor. The largest observed run-up amplitude of 17.6 meters was at Paloa, a village on the western end of the island (Okal et al. 2010). A number of homes, two churches and the elementary school were located on lowlying land close to the shore; all these buildings were either totally destroyed or greatly damaged but, due to local knowledge of natural tsunami warning signs, there was only one fatality. An upper portion of the village was undamaged and most of the people whose homes were destroyed by the tsunami were able to set up temporary shelter in the upper part of the village, co-locating with family members (personal observations by the authors). And, while tent shelters were scattered throughout the island, there were only two small areas with a large concentration of tents in the areas affected by the tsunami.

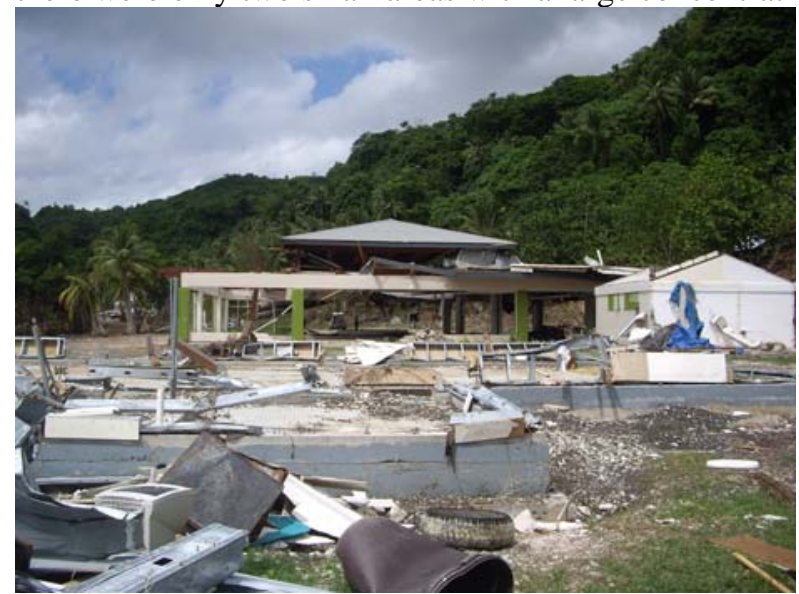

FIGURE 6: Paloa, Tutuila, American Samoa. Damages from 29 September 2009 Samoan Tsunami

There was engineered shore protection fronting most of the low-lying roadways that serve as the major transportation routes for the island. There was little damage to the roads and vehicle traffic was possible once the road was cleared of floating vehicles, boats and debris. Receeding floodwaters scoured one bridge segment, severing the road that provided the only vehicle access to the western end 
of the island as well as the water line that had been attached to the bridge structure. Temporary repairs restored vehicle access and the water supply to the western end of the island within 12 hours of the event. The airport was temporary closed until debris could be removed from the runway. The main powerplant in Pago Pago lost service when the generators were flooded. Emergency generators were quickly deployed around the island and power was restored within a few weeks; however the power station had been neither repaired nor replaced 8 months after the event and the emergency generators were still the main source of power for the eastern portion of the island (personal observations by the authors and personal communications from participants in FEMA's recovery team.)

\section{Pacifica, California: Erosion from El Niño Storms}

Pacifica, California is a coastal community that borders the Pacific Ocean. Located about 19 kilometers south of San Francisco, Pacifica has about 38,000 full-time residents and a small number of tourists and vacationers. The City has 9 kilometers of shoreline, and a few low-lying beaches. Much of the coast has narrow sand beaches backed by 12 to 30 meter high coastal bluffs.

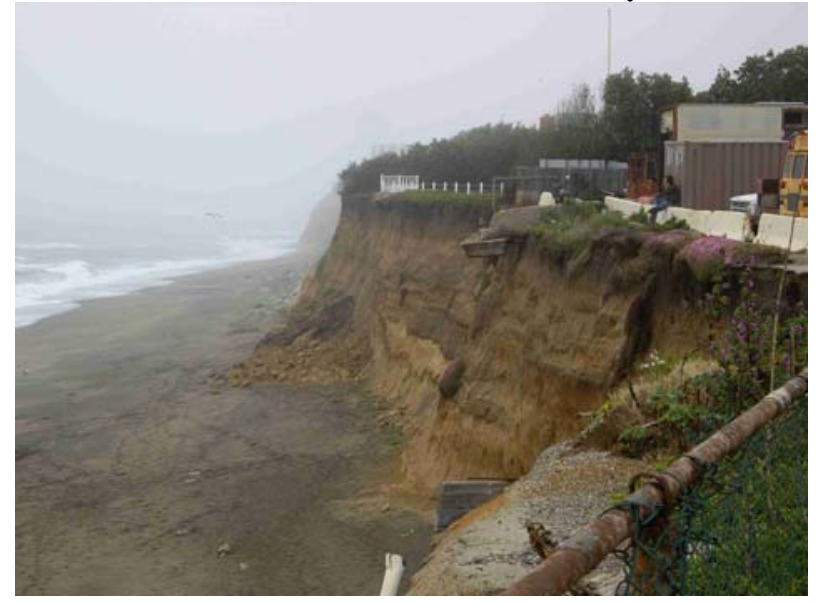

FIGURE 7: Pacifica, California. Typical coastal bluffs.

The Pacifica coast is exposed to long-period swell and during El Niño storms, the shoreline often experiences significant erosion. During the 1982/83 El Niño storms, the seaward row of mobile home sites was lost when the coastal bluff collapsed during a high storm and wave event. During the 1997/98 El Niño storms another section of coastal bluffs underwent rapid erosion, 11 homes were red tagged and 9 of them were ultimately removed from the bluff top. In 2009/2010, another season of major El Niño storms caused more erosion of the bluffs, threatening several apartment buildings. Emergency measures were taken to protect the apartment buildings from continued bluff losses, including placement of a large rock revetment at the base of the coastal bluff and a soil nail wall on the bluff face. Each storm event reduced available housing stocks, and caused closure of the local roads while construction work has been underway.

\section{Summary of Case Studies}

The three communities all have a high or very high coastal susceptibility rating and are all susceptible for damaging coastal events. Figure 8 shows the CRI for each of these three communities, drawing upon information on the community in general and knowledge of how each community responded to a recent coastal hazard event. Using the CRI, each has a very different level of resilience, based substantially upon the differences in the exposure of facilities to coastal hazards and the availability of replacement facilities. The differences in the CRIs suggest that communities' decisions can make a difference in their resilience and in their overall vulnerability to future disasters. A factor that is not yet accounted for in the CRI is the trend of the community and what changes and activities are already underway before a disaster will influence the recovery of the community. The general CRI examines the resilience of community elements in aggregate and does not examine resilience of the individual community elements. It also does not provide any information on the costs, either in terms of time and resources, or benefits from various resilience steps. 


\begin{tabular}{|l|c|c||c|}
\hline & Galveston, Texas & $\begin{array}{c}\text { Tutuila, American } \\
\text { Samoa }\end{array}$ & Pacifica, California \\
\hline $\begin{array}{l}\text { Hazard Susceptibility } \\
\text { (CVI) }\end{array}$ & Very high & High & Very high \\
\hline \hline $\begin{array}{l}\text { Community Elements } \\
\text { Exposed }\end{array}$ & $>90 \%$ & $>90 \%$ & $<10 \%$ \\
\hline $\begin{array}{l}\text { Safe Functional } \\
\text { Redundancy }\end{array}$ & Backups for 1 of 6 & Backups for 5 of 6 & Backups for 5 of 6 \\
\hline Recovery Time & $>2$ months & $2-4$ weeks & $1-2$ weeks \\
\hline $\begin{array}{l}\text { Coastal Resiliency Index } \\
\text { from 1 to 100) }\end{array}$ & $\mathbf{2 5}$ & $\mathbf{5 0}$ & $\mathbf{7 0}$ \\
\hline
\end{tabular}

FIGURE 8: CRI for Galveston, Tutuila and Pacifica Case Studies

\section{CONCLUSIONS}

Communities cannot avoid hazardous events, but by improving their resilience, they can reduce the likelihood that these events will turn into disasters. The past practice of rebuilding for the most recent disaster will increasingly leave communities vulnerable to future hazards, and to the consequences from climate change and rising sea level. As resources become scarce, communities will be less able to repeat unsustainable or non-resilient approaches to community development. Yet, many communities are not now aware of their options for improved resilience. The CRI provided a valuable tool for examining community resilience to coastal disasters. Examination of the resilience of a community over time, especially tracking the steps taken to improve or diminish resilience during the period preceding a significant hazardous event, will add to the understanding of the community recovery and the ways it rebuilds after a disaster. The evaluation of resilience for several coastal communities that have recently experienced a hazardous coastal event highlights the ability of the CRI to differentiate between various hazards and community conditions. Further refinement of the CRI will be to detail resilience by function and to add additional resilience factors that will allow communities to better evaluate options for improved resilience. An additional module for costs will enable communities to undertake a rudimentary benefit cost analysis for various resilience options and provide a starting point from with to examine large scale resilience options such as managed retreat or the installation or expansion of coastal defenses.

\section{REFERENCES}

Anthoff, D., Nicholls, R., Tol, R. S. J., and Vafeidis, A. T. (2006). "Global and regional exposure to large rises in sea-level: a sensitivity analysis." Tyndall Centre for Climate Change Research, 30.

ASCE. (2009). "2009 Report Card for America's Infrastructure." ASCE, Reston.

Colgan, C. S. (2003). "The Changing Ocean and Coastal Economy of the United States: A Briefing Paper for Conference Participants." Waves of Change: National Governors Association, Center for Best Practices, 18.

Curtis, S. A. (2007). Hurricane Katrina Damage Assessment: Louisiana, Alabama, and Mississippi Ports and Coasts, American Society of Civil Engineers, Reston.

Cutter, S. L. (2001). American Hazardscapes: The Regionalization of Hazards and Disasters, Joseph Henry Press, Washington, D.C.

Dalrymple, R. A., and Kriebel, D. L. (2005). "Lessons in Engineering from the Tsunami in Thailand." Bridge, 35(2), 4 - 13.

Ewing, L. (2008). "Coastal Forum: Coastal megacities and hazards: Challenges and opportunities." Shore and Beach, 76(4), 36 - 41. 
Ewing, L. (2009). "Sea Level Change and Implications for Coastal Engineering and Coastal Management." Handbook of Coastal and Ocean Engineering, Y. C. Kim, ed., World Scientific, Singapore.

Ewing, L., Stauble, D., Work, P. A., Edge, B. L., Rogers, S. M., Loeffler, M. U., Kaihatu, J. M., Overton, M., Waters, J. P., Suzuki, K., Dean, R. G., Garrett, M. H., Wiggins, E., and Gregory, G. H. (2009). "Field investigation of Hurricane Ike impacts to the upper Texas coast." Shore \& Beach, 77(2), 9 - 23.

FEMA. (2009). "Erosion, Scour, and Foundation Design: Hurricane Ike Recovery Advisory." D. o. H. Security, ed., Washington, DC, 8.

Grinsted, A., Moore, J. C., and Jefrejeva, S. (2009). "Reconstructing sea level from paleo and projected temperatures 200 to 2100." Society of Climate Dynamics, 34(4), 461 - 472.

Horton, R. C., Herweijer, C., Rosenzweig, C., Liu, J., Gornitz, V., and Ruane, A. C. (2008). "Sea-level rise projections for current generation CGCMs based on the semiempirical method." Geophysical Research Letters, 35, 5.

Institution for Civil Engineers. (2008). "Flooding: Engineering resilience."

IPCC. (2007). "Climate Change 2007, Synthesis Report." Intergovernmental Panel on Climate Change.

Jefrejeva, S., Moore, J. C., and Grinsted, A. (2010). "How will sea level respond to changes in natural and anthropogenic forcing by 2100?" Geophysical Research letters, 37(LO7703), 5.

Jonientz-Trisler, C., Simmons, R. S., Yanagi, B. S., Crawford, G. L., Darienzo, M., Eisner, R. K., Petty, E., and Priest, G. R. (2005). "Planning for Tsunami-Resilient Communities." Natural Hazards, 35, 121 - 139.

Komar, P. D., Allan, J. C., and Ruggiero, P. (2008). "Increasing Wave Heights along the Shores of the United States: Climate Controls and Hazards." Solutions to Coastal Disasters, L. Wallendorf, L. Ewing, C. Jones, and B. Jaffe, eds., ASCE, Oahu, 147-157.

Liu, P. L.-F., Lynett, P., Fernando, H., Jaffe, B., Fritz, H., Higman, B., Morton, R., Goff, J., and Synolakis, C. E. (2005). "Observations by the International Tsunami Survey Team in Sri Lanka." Science, 308, 1.

Mann, M. E., and Emanuel, K. A. (2006). "Atlantic Hurricane Trends Linked to Climate Change." EOS, Transactions, American Geophysical Union, 87(24), 233, 238, 241.

Mann, M. E., Emanuel, K. A., Holland, G. J., and Webster, P. J. (2007). "Atlantic Tropical Cyclones Revisited." EOS, Transactions, American Geophysical Union, 88(36), 349 - 350.

McGranahan, G., Deborah Balk, D., and Anderson, B. (2006). "Low coastal zone settlements." Tiempo(59), 23-26.

Morton, R. A., and McKenna, K. (1999). "Analysis and projection of erosion hazard areas, Galveston and Brazoria counties, Texas." Journal of Coastal Reseach(Special Issue 28), 106 - 120.

National Oceanic and Atmospheric Administration. (2010). "Adapting to Climate Change: A Training for Coastal and Marine Resource Managers."

Okal, E., Fritz, H. M., Synolakis, C. E., Borrero, J. C., Weiss, R., Lynett, P. J., Titov, V. V., Foteinis, S., Jaffe, B. E., Liu, P. L.-F., and Chan, I.-C. (2010). "Field Survey of the Samoan Tsunami of 29 September 2009." Seismological Research Letters, 81(4), 577 - 591.

Rahmstorf, S. (2007). "A Semi-Empirical Approach to Projecting Future Sea-Level Rise." Science, $315,3$.

Ruggiero, P. (2008). "Impacts of Climate Change on Coastal Erosion and Flood Probability in the US Pacific Northwest." Solutions to Coastal Disasters, L. Wallendorf, L. Ewing, C. Jones, and B. Jaffe, eds., ASCE, Oahu, 158-169.

Synolakis, C. E., and Bernard, E. N. (2006). "Tsunami science before and beyond Boxing Day 2004." Philosophical Transactions of the Royal Society, 364, 2231 - 2265.

Thieler, E. R., and Hammar-Klose, E. S. (2000). "National Assessment of Coastal Vulnerability to SeaLevel Rise: Preliminary Results for the U.S. Gulf of Mexico Coast." U. G. Survey, ed., Reston.

U.S. Indian Ocean Tsunami Warning System Program. (2007). "How Resilient is Your Coastal Community? A Guide for Evaluating Coastal Community Resilience to Tsunamis and Other Hazards." US Agency for International Development, ed., 144.

Vermeer, M., and Rahmstorf, S. (2009). "Global sea level linked to global temperature." PNAS, 106(51), 21527 - 21532. 